\title{
Clinical course of anogenital warts in men infected with human immunodeficiency virus
}

\author{
A McMillaN, P E BISHOP \\ From the Genitourinary Medicine Unit, Royal Infirmary, Edinburgh
}

SUMMARY Fifty four men with anogenital warts were studied; 22 had concurrent infection with the human immunodeficiency virus (HIV). The median duration of the warts before and after the start of treatment of seven HIV infected and 10 non-infected heterosexual men was similar. In homosexual men, however, the duration of the lesions in $15 \mathrm{HIV}$ infected patients was greater before and after treatment than in 22 non-HIV infected men. As the median number of $\mathrm{CD}^{+}{ }^{+}$cells in the peripheral blood was significantly lower in homosexual than heterosexual men infected with HIV, the difference in the course of anogenital warts in homosexual compared with heterosexual men may reflect different degrees of immunosuppression.

Anogenital warts caused by human papillomavirus (HPV) are common in patients who attend genitourinary medicine clinics and, in the absence of specific antiviral chemotherapy, can be difficult to eradicate. After variable periods, however, they usually regress, even if they have not been treated. 'The immunological mechanisms that result in resolution of wart virus infection are largely unknown, but cell mediated immune responses are probably important. ${ }^{2}$ Anogenital warts occur in about $40 \%$ of homosexual men infected with the human immunodeficiency virus (HIV), ${ }^{3}$ and, as HIV can produce pronounced impairment of cellular immunity, condylomata acuminata in men with HIV infection might be expected to have a somewhat protracted course. Surprisingly, few data on this aspect of HPV infection have been published. The aim of the present study was to learn something of the natural history of anogenital warts in men infected with HIV.

\section{Patients and methods}

\section{PATIENTS}

The study group comprised 54 men with anogenital warts who attended the department of genitourinary medicine of this hospital as "new" or "return new" patients in June to December 1984 and who were available for assessment in 1988. After October 1985,

Address for reprints: Dr A McMillan, Genitourinary Medicine Unit, Department of Medicine, Edinburgh Royal Infirmary, Lauriston Place, Edinburgh, EH3 9YW

Accepted for publication 24 February 1989 when HIV antibody testing became available, and after counselling, each of these men had requested serological testing for HIV infection: 22 had antibody to HIV. At the initial clinic attendance we took a careful history from each patient, paying particular attention to the duration of his warts before the clinic visit. After undertaking a general physical examination, we inspected the genitalia and perianal region carefully and noted the location and extent of the warts. Whenever we found perianal condylomata acuminata, we undertook proctoscopy. We collected routinely the appropriate material for microbiological examination for sexually transmissible pathogens. Depending on the sites of the warts, patients were treated with podophyllin, cryotherapy, scissor excision, or electrocautery.

As far as possible, we reviewed patients at regular intervals, when we repeated the physical examination and noted the extent of the warts. We obtained blood at intervals from most patients who had antibody to HIV, to estimate the T cell subpopulation of peripheral blood lymphocytes and the serum immunoglobulin concentrations.

\section{LABORATORY METHODS}

Serum was screened for antibodies against HIV by competitive enzyme linked immunosorbent assays. (Wellcome). Positive results were confirmed if samples reacted positively in a different assay of the antiglobulin type (Pasteur or Du Pont). A few serum samples required further investigation by immunoblotting.

The numbers of $\mathrm{CD}^{+}$and $\mathrm{CD} 8^{+}$cells in peripheral 
Table Summary of findings in 54 men with anogenital warts and biopsy specimens from 32 of them

\begin{tabular}{|c|c|c|c|c|c|}
\hline \multirow[b]{2}{*}{ Patient groups } & \multirow[b]{2}{*}{$\begin{array}{l}\text { No of patients in } \\
\text { each group }\end{array}$} & \multirow[b]{2}{*}{$\begin{array}{l}\text { Median (range) age of patients } \\
\text { (years) }\end{array}$} & \multicolumn{3}{|c|}{ Location of warts } \\
\hline & & & $\begin{array}{l}\text { Sub-preputial } \\
\text { only }\end{array}$ & $\begin{array}{l}\text { Perianal/anal } \\
\text { only }\end{array}$ & Both sites \\
\hline $\begin{array}{l}\text { Homosexual men: } \\
\text { HIV infected } \\
\text { Non-HIV infected }\end{array}$ & $\begin{array}{l}15 \\
22\end{array}$ & $\begin{array}{ll}26 & (21-41) \\
23 & (19-53)\end{array}$ & $\begin{array}{l}0 \\
0\end{array}$ & $\begin{array}{l}12 \\
20\end{array}$ & $\begin{array}{l}3 \\
2\end{array}$ \\
\hline $\begin{array}{l}\text { Heterosexual men: } \\
\text { HIV infected } \\
\text { Non-HIV infected }\end{array}$ & $\begin{array}{r}7 \\
10\end{array}$ & $\begin{array}{ll}24 & (22-32) \\
22 & (20-31)\end{array}$ & $\begin{array}{l}3 \\
0\end{array}$ & $\begin{array}{l}1 \\
7\end{array}$ & $\begin{array}{l}3 \\
3\end{array}$ \\
\hline
\end{tabular}

*Each man infected through intravenous drug abuse.

blood were measured by flow cytofluorimetry, and serum immunoglobulin concentrations were estimated by radial immunodiffusion.

We obtained biopsy samples of the warts of 32 men, which were examined histologically. The type of infecting HPV was assessed by in situ hybridisation using probes HPV $6 \mathrm{~b}, 11,16$, and $18 .^{4}$

\section{STATISTICAL METHODS}

We used the Wilcoxon rank test to analyse the data.

\section{Results}

The table summarises the findings in the study groups. In each case, the warts were of the hyperplastic type.'

\section{CLINICAL COURSE OF ANOGENITAL WARTS}

\section{Heterosexual men}

Of 17 heterosexual men available for assessment three years after the initial clinic attendance, seven had antibody to HIV, each having acquired his infection by sharing contaminated syringes and needles. Thirteen heterosexual men had perianal condylomata, but warts were not found within the anal canal. The differences between HIV infected and non-infected men in the median duration of the warts before treatment ( $9 v 3$ months), the duration after the start of treatment ( $24 v 9$ months), or the number of treatments required $(10 v 5)$ were not significant.

\section{Homosexual men}

The median duration of anogenital warts before treatment was significantly higher $(p<0.01)$ in HIV infected men than in non-infected men. Similarly, the median duration of warts after the start of treatment (36 $v 9.5$ months) and the median number of treatments given $(20 v 4)$ were significantly greater in men infected with HIV (in each case $p<0.01$ ). Sixteen men (seven with and nine without antibodies to HIV) had condylomata of the anal canal, which were not treated other than by obtaining tissue by punch biopsy for histological examination (data not shown). The median durations of these lesions were 36 months in HIV infected men and 14 months in non-infected men $(p<0.05)$, though the forms of treatment used for each group were similar.

\section{Immunological variables}

Data on the number of $\mathrm{CD}^{+}$cells in the peripheral blood and serum immunoglobulin concentrations were available in $14 \mathrm{HIV}$ infected (nine homosexual and five heterosexual) men who attended during March 1988. The median number of $\mathrm{CD}^{+}$cells in blood from the homosexual men $\left(0.1 \times 10^{9} / 1\right.$, range $0.04-0.47$ ) was significantly smaller than from the heterosexual men $\left(0.45 \times 10^{9} / 1\right.$, range $\left.0.38-0.59\right)(\mathrm{p}<$ $0 \cdot 02$ ). No significant differences were seen, however, in median serum IgG, IgA, or IgM concentrations in homosexual compared with heterosexual men (data not shown).

\section{Type of $\mathrm{HPV}$}

Formalin fixed paraffin blocks were available for in situ hybridisation from 32 of the 54 patients, of which $23(72 \%)$ gave positive results for HPV $6 \mathrm{~b} / 11$. In addition to HPV 6b/11, HPV 18 was detected in two patients (both homosexual men with antibody to HIV) and HPV 16 in one (a homosexual man with no antibody to HIV).

\section{Discussion}

Although the precise immunological mechanisms that result in regression of anogenital warts are uncertain, as florid and recalcitrant lesions may occur in patients with defects of cellular immunity, ${ }^{2}$ cell mediated immunity appears to play an important part. HIV is associated with the progressive impairment of cell mediated immunity, ${ }^{5}$ and warts in patients infected with HIV might be expected to have a prolonged course. The heterosexual men in our study, however, showed no significant difference in the median durations of warts before treatment, durations after the 


\begin{tabular}{|c|c|c|c|c|c|}
\hline \multicolumn{2}{|c|}{ Mean (range) duration of warts (months) } & \multirow{2}{*}{$\begin{array}{l}\text { Median (range) No of } \\
\text { treatments }\end{array}$} & \multicolumn{3}{|c|}{$\begin{array}{l}\text { No of biopsy specimens/No examined } \\
\text { containing HPV types: }\end{array}$} \\
\hline Before treatment & After start of treatment & & $6 b / 11$ & 16 & 18 \\
\hline $\begin{array}{rr}12 & (1-48) \\
2 & (1-12)\end{array}$ & $\begin{array}{cc}36 & (14-64) \\
9 \cdot 5 & (2-24)\end{array}$ & $\begin{array}{rr}20 & (3-40) \dagger \\
4 & (1-27) \ddagger\end{array}$ & $\begin{array}{c}7 / 8 \\
10 / 17\end{array}$ & $\begin{array}{l}0 / 8 \\
1 / 17\end{array}$ & $\begin{array}{l}2 / 8 \\
0 / 17\end{array}$ \\
\hline $\begin{array}{ll}9 & (2-24) \\
3 & (2-12)\end{array}$ & $\begin{array}{rr}24 & (15-36) \\
9 & (3-24)\end{array}$ & $\begin{array}{rr}10 & (1-20) \S \\
5 & (1-17) \|\end{array}$ & $\begin{array}{l}0 \\
6 / 7\end{array}$ & $\begin{array}{l}0 \\
0 / 7\end{array}$ & $\begin{array}{l}0 \\
0 / 7\end{array}$ \\
\hline
\end{tabular}

tFive men treated by cryotherapy only, four with podophyllin only, five with both podophyllin and cryotherapy, and one by scissor excision under local anaesthesia.

†Seven men treated with podophyllin only, six by cryotherapy only, six with both podophyllin and cryotherapy, and three by scissor excision.

$\S$ Three men treated by cryotherapy. three with podophyllin only, and one by scissor excision.

iSeven men treated with podophyllin only and three by cryotherapy.

start of treatment, or numbers of treatments given to HIV infected compared with non-infected men. The total number of patients, however, was small, and a larger series of patients would be required to confirm or refute these findings.

The homosexual men in our study showed a significant difference in the course of the warts between HIV infected and non-infected men. Although intraanal warts are known to have a more protracted course, even in the absence of immunodeficiency, ${ }^{6}$ in our patients, the duration of perianal and anal warts was greater in men with antibody to HIV. This finding differed from that of von Krogh et al, who found that $32.1 \%$ of men with and $40.4 \%$ of men without antibody to HIV had anal warts for more than 12 months, a difference that was not significant. ${ }^{6}$ The duration of follow up of their patients was not stated, however, and more prolonged surveillance may have shown a significant difference between the two groups. Another factor that may explain the differences between our findings and those of von Krogh and the differences in durations of warts between our homosexual and heterosexual patients could be the degree of impairment of cell mediated immunity.

As the duration of HIV infection increases, there is a progressive reduction in the number of $\mathrm{CD}^{+}$cells in the peripheral blood and progressive impairment of cellular immunity. ${ }^{5}$ In our patients, the median number of $\mathrm{CD}^{+}$cells in the blood of HIV infected homosexual men was significantly lower than in heterosexuals. That may reflect differences in the duration of HIV infection or in exposure to antigenic stimuli such as spermatozoa. Thus the differences between our homosexual and heterosexual HIV infected patients in the course of anogenital warts may result from differences in degrees of impairment of cellular immunity.

Although intraepithelial carcinoma has been recorded in HIV infected men with anal warts,' we did not find this in any of the biopsied lesions. Human papillomavirus types 16 or 18 , which are associated with genital tract malignancy, ${ }^{8}$ were detected by in situ hybridisation in warts from three of our patients, two of whom had antibody to HIV. Rüdlinger $e t$ al, however, did not identify these types in perianal or anal warts from HIV infected men or women in Zürich. ${ }^{9}$ As HPV types 16 and 18 tend to be associated with non-condylomatous lesions, ${ }^{10}$ and as colposcopy of the anal canal was not undertaken, the prevalence may be higher than recorded in those two studies.

In conclusion, our data suggest that anogenital warts in HIV infected homosexual men run a protracted course, but anal malignancy appears to be uncommon. As HPV types associated with carcinomas of the anogenital regions can be identified in genital and anal condylomata, the perianal region and anal canal should be examined regularly to detect early neoplastic changes.

We thank Dr S Fletcher for histologically examining the warts, Dr P L Yap for measuring serum immunoglobulin concentrations, Dr C M Steel for analysing peripheral blood T cell subset populations, Mr R Morris and Mrs K Sizer for performing in situ hybridisation, and Dr J F Peutherer for testing for antibody to HIV. We gratefully acknowledge the financial support of the Biomedical Research Committee of the Scottish Home and Health Department (Grant No $\mathrm{K} / \mathrm{MRS} / 50 / \mathrm{C} 851$ ).

\section{References}

1 Oriel JD. Natural history of genital warts. British Journal of Venereal Diseases 1971:47:1-13.

2 Morison WL. Viral warts. herpes simplex and herpes zoster in patients with secondary immune deficiencies and neoplasms. Br J Dermatol 1975:92:625-30.

3 Evans BA. Dawson SG. McLean KA. et al. Sexual lifestyle and clinical findings related to HTLV-III LAV status in homosexual men. Genitourin Med 1986:62:384-9.

4 Wells M. Griffiths S. Lewis F. Bird CC. Demonstration of human papilloma virus types in paraffin processed tissue from human 
ano-genital lesions by in situ DNA hybridisation. J Pathol 1987; 152:77-82.

5 Moss AR, Bacchetti P, Osmond D, et al. Seropositivity for HIV and the development of AIDS or AIDS related condition: three year follow up of the San Francisco General Hospital cohort. Br Med J 1988;296:745-50.

6 von Krogh G, Syrjänen S, Syrjänen K. Anal condylomas in homosexual/bisexual and heterosexual males. I. Clinical assessment. In: Oriel JD, Waugh M, eds. Anglo-Scandinavian conference on sexually transmitted diseases. London: Royal Society of Medicine, 1988:90.

7 Croxson T, Chabon AB, Rorat E, Barash IM. Intraepithelial carcinoma of the anus in homosexual men. Dis Colon Rectum 1984;27:325-30.

8 zur Hausen H, Gissmann L, Schlehofer JR. Viruses in the aetiology of human genital cancer. Prog Med Virol 1984;30:170-86.

9 Rüdlinger R, Grob R, Buchmann P, Christen D, Steiner R. Anogenital warts of the condyloma acuminatum type in HIV positive patients. Dermatologica 1988;176:277-81.

10 Gross G, Ikenberg H, Gissmann L, Hagedorn M. Papillomavirus infection of the anogenital region: correlation between histology, clinical picture, and virus type. Proposal of a new nomenclature. J Invest Dermatol 1985;85:147-52. 